\title{
CAMBRIDGE JUURALS
}

\section{New in 2014}

\section{Journal of Experimental Political Science}

Published for the Experimental Research Section of the American Political Science Association

\section{Editors}

Rebecca B. Morton, New York University, USA

Joshua A. Tucker, New York University, USA

The Journal of Experimental Political Science (JEPS) features research - be it theoretical, empirical, methodological, or some combination thereof that utilizes experimental methods or experimental reasoning based on naturally occurring data. We define experimental methods broadly: research featuring random (or quasi-random) assignment of subjects to different treatments in an effort to isolate causal relationships between variables of interest. JEPS embraces all of the different types of experiments carried out as part of political science research, including survey experiments, laboratory experiments, field experiments, lab experiments in the field, natural and neurological experiments.

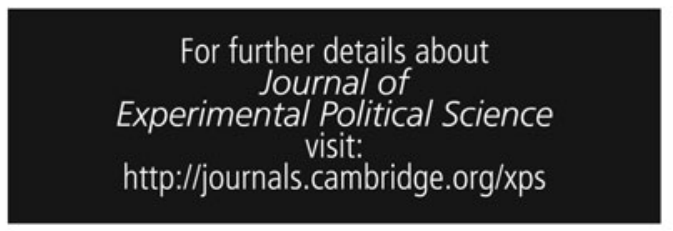

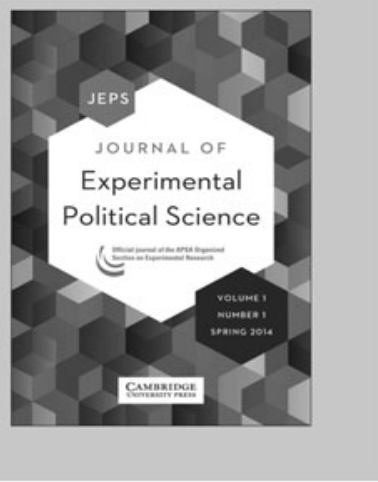

Journal of Experimental Political Science

is available online at: http://journals.cambridge.org/xps

To subscribe contact Customer Services

in Cambridge:

Phone +44 (0) 1223326070

$\mathrm{Fax}+44(0) 1223325150$

Email journals@eambridge.org

in New York:

Phone +1 (845) 3537500

Fax $+1(845) 3534141$

Email

subscriptions_newyork@cambridge.org

Free email alerts

Keep up-to-date with new material - sign up at

journals.cambridge.org/xps-alerts 


\section{CAMBRIDGE JULNALS}

\section{British \\ Journal of Political \\ Science}

\section{Editors}

Shaun Bowler, University of California, Riverside, USA

Sona Golder, Penn State University, USA

Robert Johns, University of Essex, UK

René Lindstädt, University of Essex, UK

Hugh Ward, University of Essex, UK

The British Journal of Political Science (BJPo/S) is a broadly based journal aiming to cover developments across a wide range of countries and specialisms. Contributions are drawn from all fields of political science (including political theory, political behaviour, public policy and international relations), and articles from scholars in related disciplines (sociology, social psychology, economics and philosophy) appear frequently. With a reputation established over 40 years of publication, the BJPO/S is widely recognised as one of the premier journals in its field.
British Journal of Political Science : = in
British Journal of Political Science is available online at:

http://journals.cambridge.org/bjpols

To subscribe contact Customer Services

in Cambridge:

Phone +44 (0)1223 326070

$\mathrm{Fax}+44(0) 1223325150$

Email journals@cambridge.org

in New York:

Phone (845) 3537500

Fax (845) 3534141

Email

subscriptions_newyork@cambridge.org

\section{Free email alerts}

Keep up-to-date with new material - sign up at

journals.cambridge.org/jps-alerts 


\section{Politics E Gender}

\section{INSTRUCTIONS TO CONTRIBUTORS}

\begin{abstract}
Politics \& Gender accepts manuscript submissions through the Editorial Manager system at http://www.editorialmanager.com/pag

For questions concerning "Instructions to Contributors," please contact the Editors at politicsandgender@ou.edu. Additional information can be found at the journal's website at http://www.journals.cambridge.org/action/display Journal?jid=PAG
\end{abstract}

\section{BOOK REVIEWS}

Suggestions of books to be reviewed should be emailed to the Book Review Editor:

Sabine Lang

Politics \& Gender

University of Washington

pgbooks@uw.edu

\section{MANUSCRIPT PREPARATION}

- Manuscripts must be no longer than 30 pages including text, tables and figures, references and appendices. The entire manuscript (including notes and references) must be double-spaced, with one-inch margins and 12-point font, and printed on one side of the page only.

- The author must include a separate title page, with his or her full contact information (including email address, telephone number and institutional affiliation), and a brief biographical statement. All identifying information must be removed from the manuscript.

- A second page must include an abstract of no more than 200 words.

- Placement of tables or figures should be cited in the text. The publisher will be responsible for placing artwork, tables or figures, as well as converting endnotes to footnotes.

- Appendices, tables, and figures should be numbered consecutively throughout the article and be included on separate pages appearing after the reference section. Figures should be ready for photographic reproduction; they cannot be redrawn by the publisher. Charts, graphs, or other artwork should be professional rendered or computer generated as TIFF or EPS files. Photographs should be clearly printed and should remain legible after a $50 \%$ reduction.

- References and notes should conform to the APSA Style Manual. Authors should include full volume, issue, and page numbers for references. Author's acknowledgments or other personal notes will appear as an unnumbered note at the foot of the first page. Notes should be numbered consecutively throughout the article. Numbered notes should appear at the end of the sentence. If multiple texts are cited in a sentence, they should appear as one consolidated note at the end of the sentence.

- Endnotes should be employed (rather than footnotes).

- All figure captions should be typed on a separate page (or pages), rather than on the figures themselves (which are camera-ready TIFF or EPS files) so that they can be copyedited.

Originality and copyright: Papers with multiple authors are reviewed with the assumption that all authors concur with its submission. A Copyright Transfer Agreement, with certain specified rights reserved by the author, must be signed and returned to the Editor by senior authors of accepted manuscripts, prior to publication. Politics \& Gender does not accept manuscripts for review that are under review elsewhere, previously published or already committed for publication.

For general guidelines for preparing a manuscript for submission, please refer to the APSA Style Manual for Political Science (rev. ed. 2001) for citation, footnotes, references, and other style issues. Please note, in particular, the statement on gender-specific language (15). 


\section{Politics E Gender}

\section{Volume 11 | Number 2 | June 2015}

\section{ARTICLES}

Double-Bind on the Bench: Citizen Perceptions of Judge Gender and the Court

Kjersten Nelson

Lawyers, Gender, and Money: Consensus, Closure, and Conflict in the

Global Financial Crisis

Wesley Widmaier

Playing the Gender Card: The Uses and Abuses of Gender in Australian Politics

Carol Johnson

Intersecting Identities, Divergent Views: Interpreting the Experiences of

Women Politicians in the Pacific Islands

Jack Corbett and Asenati Liki

Gender Quotas and Ethnic Minority Representation: Swedish Evidence

from a Longitudinal Mixed Methods Study

Olle Folke, Lenita Freidenvall and Johanna Rickne

Reconceptualizing Work and Building Ruddick's Feminist Solidarity Transnationally

Sally J. Scholz

\section{CRITICAL PERSPECTIVES ON GENDER AND POLITICS}

Introduction: Feminist Security Studies and Feminist Political Economy:

Crossing Divides and Rebuilding Bridges

Juanita Elias

From Unity to Divergence and Back Again: Security and Economy in

Feminist International Relations

Laura Sjoberg

(Re)framing the Relationship between Discourse and Materiality in

Feminist Security Studies and Feminist IPE

Heidi Hudson

A Tale of Two Feminisms in International Relations? Feminist Political

Economy and the Women, Peace and Security Agenda

Jacqui True

The Everyday Gendered Political Economy of Violence

Juanita Elias and Shirin Rai

Feminist Security Studies and Feminist International Political Economy:

Considering Feminist Stories

Katherine Allison

Closing Reflection: Militiamen Get Paid; Women Borrowers Get Beaten

Cynthia Enloe

BOOK REVIEWS

\section{Cambridge Journals Online}

For further information about this journal please

go to the journal website at:

journals.cambridge.org/pag

\section{CAMBRIDGE} UNIVERSITY PRESS 